\title{
Disposable diapers problem and its regulations in Mexico
}

\section{Problema de pañales desechables y sus regulaciones en México}

\author{
SERRANO-FARFÁN, Angélica Rocío† \& NIVÓN-PELLÓN, Alejandra* \\ Universidad Autónoma de Querétaro, Mexico.
}

ID $1^{\text {st }}$ Author: Angélica Rocío, Serrano-Farfán / ORC ID: 0000-0001-9122-5704, CVU CONACYT ID: 840147

ID $1^{\text {st }}$ Co-author: Alejandra, Nivón-Pellón / ORC ID: 0000-0002-1715-4335, Researcher ID Thomson: V-8717-2018, CVU CONACYT ID: 668097

DOI: $10.35429 /$ JSTA.2021.19.7.9.17

Received January 15, 2021; Acceptance June 30, 2021

\begin{abstract}
Disposable diapers are the modern solution to keep babies' skin dry and clean since they are efficient, a single diaper can keep a baby clean and dry for up to eight hours and they are effective due to the manufacturing materials that are waterproof, flexible, resistant and highly absorbent. While these are advantages to the layered design of the disposable diaper, they become barriers that prevent degradation. In Mexico, 14\% of the solid waste generated corresponds to this waste. In the present work, a systematic and exhaustive review is made of the trends, regulations, and regulations that govern the commercialization and possible improvements to the disposable diaper considered a product whose usability is highly accepted and disseminated. The foregoing to prospect the development of this product and orient it towards a more sustainable future to manage the relevant innovations and changes in the regulations that correspond to disposable diapers in the framework of development: social, economic, and environmental that raises the 2030 agenda.
\end{abstract}

Disposable diapers, Ecolabelling, LCA

\begin{abstract}
Resumen
Los pañales desechables son la solución moderna para mantener la piel de los bebés seca y limpia ya que son eficientes, un solo pañal puede mantener limpio y seco a un bebé hasta por ocho horas y son eficaces debido a los materiales de fabricación que son impermeables, flexibles, resistentes y altamente absorbentes. Si bien estas son ventajas para el diseño de capas del pañal desechable, éstas se convierten en barreras que impiden su degradación. En México el $14 \%$ de los de los residuos sólidos generados corresponden a este residuo. En el presente trabajo se hace una revisión sistemática y exhaustiva de las tendencias, regulaciones y normativa que rigen la comercialización y posibles mejoras al pañal desechable considerado un producto cuya usabilidad es altamente aceptada y difundida. Lo anterior con la finalidad de prospectar el desarrollo de este producto y orientarlo hacia un futuro más sostenible para gestionar las innovaciones pertinentes y cambios en la normativa que corresponda a los pañales desechables en el marco del desarrollo: social, económico y ambiental que plantea la agenda 2030.
\end{abstract}

Pañales desechables, Ecoetiquetas, Análisis de ciclo de vida

Citation: SERRANO-FARFÁN, Angélica Rocío \& NIVÓN-PELLÓN, Alejandra. Disposable diapers problem and its regulations in Mexico. Journal of Scientific and Technical Applications. 2021. 7-19:9-17.

\footnotetext{
* Correspondence to Author (Email: alejandra.nivon@uaq.mx)

$\dagger$ Researcher contributing as first author.
} 


\section{Introduction}

The current design of the disposable diaper is the result of an engineering process that has managed to develop from the hourglass-shaped design to the implementation of superabsorbent polymers, making each diaper more efficient for up to twelve hours (Sotelo Navarro, 2017). As is already known, the main objectives of disposable diapers are to absorb and retain the waste that the baby's body eliminates.

For more than eight decades the diaper industry has developed material technology so that disposable diapers are lighter, compact, highly absorbent, leak-resistant, and easier to use, due to this it has been adopted as an effective way to keep babies dry and clean daily (EDANA, 2019). Due to its efficiency and effectiveness, it has been adopted by $95 \%$ of parents in developed countries as the solution to keep babies' skin healthy. The benefits that disposable diapers offer to modern society are extensive, although the most important and the reason why it has been widely accepted in the market is that it does not require maintenance before or after use (SEMARNAT, 2016).

Due to the aforementioned importance of disposable diapers for today's society, a systematic review of scientific references and regulations governing this highly distributed product is carried out, to make an analysis and propose a prospective by making visible the standards that regulate the commercialization and introduction of new products to the Mexican market. The foregoing, to make a strategic approach that establishes the guidelines and requirements when projecting pertinent and desirable changes to a product of proven and extended usability to be sustainable within the framework of the economic, environmental, and social development objectives of the 2030 agenda.

\section{Innovation in disposable baby diapers}

The baby's skin is especially sensitive and is susceptible to irritability, spots, dryness, and rashes, this due to the maturity in which the baby is born since it is five times thinner than that of an adult. "Thanks to the advent of disposable cellulose diapers, the prevalence of diaper rash has dramatically decreased compared to the era of woven diapers." (Muñoz, 2003).
Dermatitis caused by the use of diapers is related to the excessive hydration of the skin, the damage generated by the friction of the materials with the baby's skin, and the increase in the $\mathrm{PH}$ level of the mixture of urine with feces. These are the factors that trigger inflammation, which is a natural mechanism that tries to repair the skin, but by not stopping the process, this generates dermatitis and/or severe dermatitis (Blume-Peytavi \& Kanti, 2018). Because of this, diaper innovation has focused on improving absorption and reducing moisture return. Increased technology development to design lighter and more absorbent materials that can be used in disposable diapers (Mendoza J. M., D’Aponte, Gualtieri, \& Azapagic, 2018). However, the implementation of biomaterials to the layering of disposable diapers has not been carried out. The innovation and development of highly biodegradable materials are prevalent when it is known that the United Nations Environment Program (2016) indicates that 14\% of the solid waste generated in Mexico corresponds to disposable diapers.

Babies use about 4 diapers a day, on average, therefore, in one year it will use 1,460 pieces, and in two years 2,920 (Procuraduría Federal del Consumidor, 2019). If we consider that in 2018 more than 2 million girls and boys were born (Conaco and Servytur México, 2018) and in Mexico, this product has a market penetration of $68 \%$, it is estimated that, in 12 months, more than 5 billion diapers were discarded (Vázquez Morillas, Espinosa Valdemar, Beltrán Villavicencio, \& Velasco Pérez, 2016).

The disposable diaper makes resources more efficient, increasing its absorption capacity and effectively eliminating runoffs and leaks, as well as improving the quality of life of babies, but as it is a product that responds to the demand of a mass-market segment, which consumes and discards in a short time, the materials are not suitable since they are highly polluting and not very degradable, being incoherent to the environmental crisis that humanity faces, for this it is necessary to regulate their life cycle, materials and create certifications dictated from of a normative framework. 
Reducing the negative environmental impact of cities, focusing efforts on improving air quality and municipal waste management is part of the objectives of the 2030 agenda, as well as reducing waste generation through prevention, reduction, recycling, and reuse. The Sustainable Development Goals were raised in an appeal to the Members of the United Nations in 2015 due to the environmental crisis faced worldwide (Government of Mexico, 2020). For the aforementioned reasons, it is important and pertinent to make regulations and prospect regulatory options or certifications that help Mexico to guarantee sustainable consumption and production modalities for this type of disposable products.

\section{Methodology}

A systematic review of scientific articles, Mexican Official Standards, and indexed journals as an exploratory and analytical technique was carried out to obtain relevant information on diaper production, product design, materials used, environmental impact, regulations, and standards that must be met for them to be commercialized in the Mexican territory and thus be able to make visible the regulations that regulate the environmental impact of this type of waste in Mexico and prospect for certifications and standards that comply with the objectives of sustainable development.

\section{Results}

\section{Components and materials of a disposable} diaper for babies

As part of the methodology, a review of the literature on layer design and the materials used in disposable diapers is presented.

The design of disposable diapers is very similar among the representative brands in the market, so the layers and components of the diapers can be well-identified.

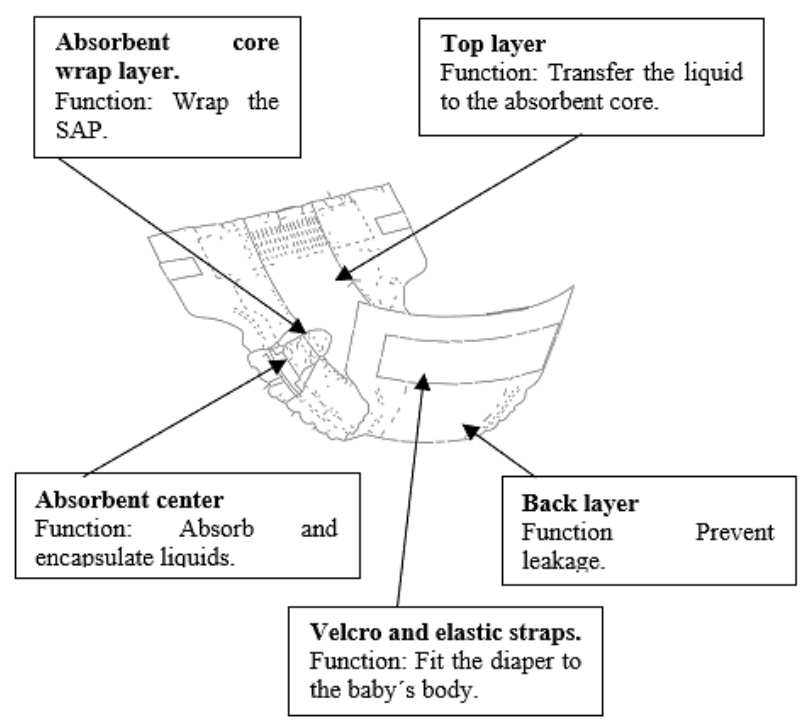

Figure 1 Layers and elements of a disposable baby diaper Source: Own elaboration, with information from EDANA (2019).

In Figure 1, the main layers of a disposable baby diaper are identified: the upper layer, which is in contact with the baby's skin, its function is to allow the passage of fluids to the next layer, which is the layer of distribution that allows the superabsorbent polymer to saturate evenly; the third layer is the absorbent center made from a polymer that can absorb 300 times its dry weight (Pozos Vázquez, Blanco Padilla, Mercado González, \& Vélez Martínez, 2018), the fourth layer is waterproof, which prevents liquids leak out of the diaper (Sotelo Navarro, 2017).

As EDANA (2019) indicates, the layers that make up disposable baby diapers are made from polyethylene and polypropylene, which can take up to 500 years to decompose (Vázquez Morillas, Espinosa Valdemar, Beltrán Villavicencio, \& Velasco Pérez, 2016).

The development of synthetic polymers is one of the great advances of the 20th century and due to their characteristics, they make them very versatile. However, the fact that this material comes from non-renewable sources and is highly resistant to corrosion, oxidation, and bacterial decomposition makes it a material that is not very friendly to the environment, forcing the industry to look for new biopolymer proposals that satisfy the requirements of the design of each product (Vázquez Morillas, Espinosa Valdemar, Beltrán Villavicencio, \& Velasco Pérez, 2016). 
The need to replace polymers with biopolymers or materials that come from renewable sources is becoming a priority for the industries that manufacture disposable products. This is due to the consumption strategy on the part of companies since there is a growing interest of consumers to seek new alternatives that keep babies clean and dry (Mirabella, Castellani, \& Sala, 2013).

\section{Life Cycle Assessment of disposable diapers}

The life cycle analysis (LCA, for its acronym in English) should be projected before marketing any product, especially in those, whose useful life is short as in the case of disposable diapers for babies (Cordella, Bauer, Lehmann, Schulz, \& Wolf, 2015).

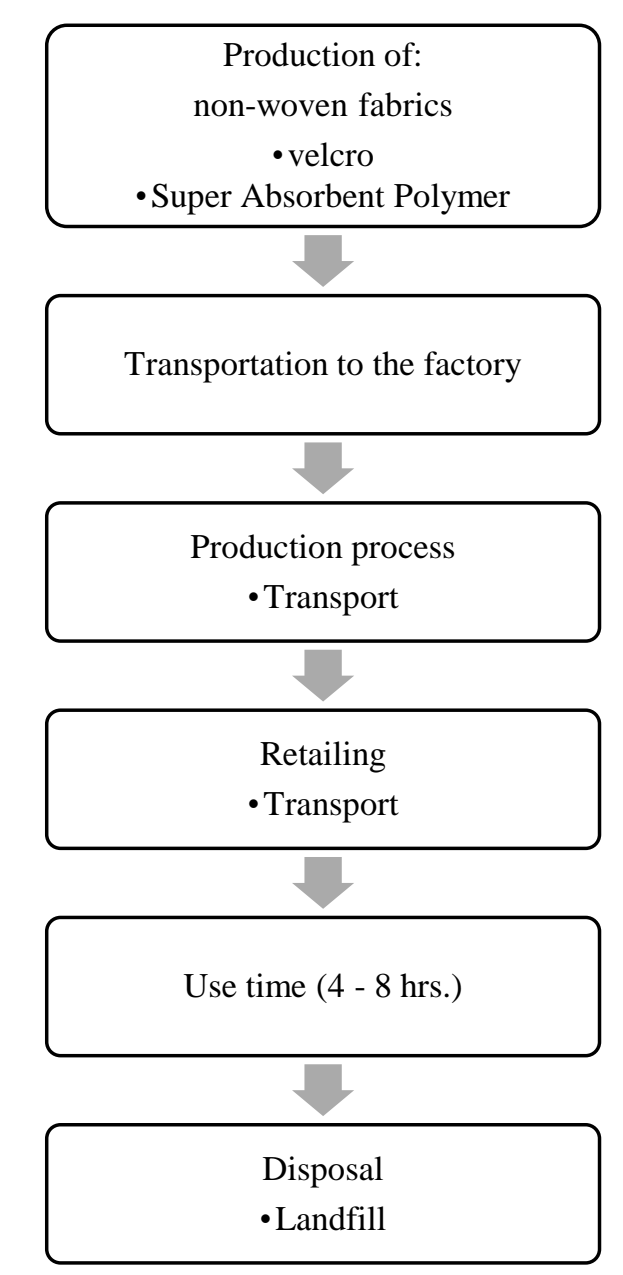

Figure 2 Diagram of the life cycle analysis of a disposable baby diaper

Source: Own elaboration
In Figure 2, the life cycle (LCA) of a disposable baby diaper is described, which begins in the extraction and processing of the raw materials that are: the superabsorbent polymer, polypropylene, and polyethylene, which are used in the manufacture of non-woven fabrics, elastics, velcro, and glues. Subsequently, these materials are taken to the production plants of each company, so that the layers are finally assembled and cut to size and manufacturing design. For their distribution, they are packaged in polyethylene bags that are packed in cardboard boxes that will be distributed at points of sale in the Mexican territory. The use time of the product, on average for each disposable diaper, is six hours, which, upon completion, is discarded to be taken to landfills.

The linear model of use and disposal of products known as Cradle to Grave (C2G), is unsustainable because the materials used in the design of disposable diapers are not recovered or recycled. and are taken to landfills without generating value, while the circular model, Cradle-to-Cradle (C2C) proposes economic growth that can be achieved sustainably through the design and manufacture of products within a closed cycle of materials, that ultimately, at the end of their life cycle, they return to be considered raw materials. The technology of these products linearly reaches the consumer, in which companies generate innovative products (trainees, pull-ups, ultra-dry, among others) with resources from different parts of the world, launching globalized products that are generated from the exploitation of natural resources in an excessive way (Gavito, et al., 2017).

Designing $\mathrm{C} 2 \mathrm{C}$ disposable products from their planning phase, useful life and the end of their life is imperative for the design of disposable products such as diapers (Hauschild, Rosenbaum, \& Olsen, 2018).

The Public Waste Agency of Fland, Belgium, developed a tool called Ecolizer 2.0, employing points it evaluates the environmental load of the designed products, to identify which stage of the product's life cycle has the greatest impact. There are more than one hundred and five ways to analyze the life cycle of products. These tools are strategies that designers and industries should use to reduce an environmental load of their products and produce under the C2C Cradle to Cradle model (OVAM, 2020). 
An eco-efficiency and circular economy life cycle analysis study has shown that by eliminating an element of the design of disposable diapers such as glue, it could reduce their environmental impact, increasing their ecoefficiency from $7 \%$ to $170 \%$ (capital/impact), this is because the extraction, manufacturing, processing, and transportation of an element of the diaper design would be eliminated, thus reducing the environmental burden and increasing the economic efficiency of the product (Mendoza J., D’ Aponte, Gualtieri, \& Azapagic, 2018).

The technologies developed for disposable diapers have been highly polluting: they generate sanitary risks, erode biological and cultural diversity, deplete natural resources and, consequently, do not conserve resources, do not improve the quality of life, nor are they sustainable (Gavito et al., 2017). The seriousness of the problem is the lack of communication of these aspects to the consumer, excluding him from the responsibility of consuming disposable products.

\begin{abstract}
Well-informed purchasing decisions by consumers can guide the industry to generate more and better products and services that are responsible for the environment and society. According to the International Organization for Standardization, consumers are increasingly interested in the less tangible attributes of products, such as ethical and environmental aspects. " (Pacific Alliance. Chile Mexico Cooperation Fund, 2017)
\end{abstract}

Well-informed purchase affects the amount of waste generated. If the consumer is educated about the products, they consume and the processes that are required for their manufacture, as well as their treatment and disposal, they could change their consumption habits, in such a way that they have a lower environmental burden (Mahecha Bustos \& Romero Venegas, 2021). Taking into account the above, pertinent and desirable is the design of a regulation that regulates and evaluates the life cycle analysis (LCA) and evaluates the environmental impact of the products marketed within the Mexican territory, instead of allowing certain levels of pollutants. in the air when incinerating solid waste such as NOM-098SEMARNAT-2002 (Ministry of the environment and natural resources, 2004), (Pacific Alliance. Chile Mexico Cooperation Fund, 2017) (Hauschild, Rosenbaum, \& Olsen, 2018).

\section{Disposable diapers regulations}

The Official Mexican Standards (NOM) that regulate trade within Mexican territory pertinent to disposable diapers are related to the information that the manufacturer provides on its packaging (Ministry of Economy, 2019). The Official Mexican Standards are listed below:

NOM-002-SCFI-2011 "Prepackaged
Products - Net Content - Tolerances and
Verification Methods."

NOM-030-SCF-2006 "Commercial information - Declaration of quantity on the label - Specifications."

\section{NOM-050-CFI-2004 "Commercial information - General provisions for products".}

In addition to the Official Mexican Standards, the Mexican Standards (NMX) can also be analyzed, which are issued by the National Institute for Textile Standardization, which is in charge of designing, distributing, and selling the pertinent standards for diapers and urine absorbent aids. (National Institute of Textile Standardization, A.C., 2020).

The Mexican Standards (NMX) are laboratory test methods that measure the maximum liquid absorption capacity that it retains inside when the absorbent material of the diapers is saturated, the moisture regression when absorbing a certain amount of liquid and the speed of absorption, however, these are not mandatory for their commercialization in the country. The companies that use these standards are those that produce disposable diapers and use them to verify the quality of the diaper they are marketing (Secretaria de Economía, 2016). Below is a list of Mexican Standards according to the characteristics of disposable diapers.

\section{NMX-A-024-INNTEX-2012 "Textile Industry-Non-Woven - Diapers - Determination of moisture return and absorption rate in disposable baby diapers- Test method."}

NMX-A-049/1-INNTEX-2009 "Textile Industry - Urine absorbent auxiliaries Part 1 - full product test." 


\begin{abstract}
NMX-A-259/2-INNTEX-2009 "Textile Industry - Determination of the $\mathrm{pH}$ of the aqueous extract Part 2- $\mathrm{pH}$ of diapers and disposable sanitary napkins - Test method."
\end{abstract}

\section{Ecolabelling}

Ecolabels are a type of ecological certification that validates a quality process. It is awarded to products or services that are less harmful to the environment than their competitors. It is a certified authority that grants the ecolabel and does so by analyzing the life cycle of the product, from extraction to disposal and treatment (OVAM, 2020). The objective of ecolabels is that products that comply with these environmentally friendly processes are recognized with a special logo on the packaging and can be identified by the consumer. Ecolabels are a strategy that countries are implementing to promote products whose life cycle has a lower environmental impact than their competitors. Around the world, these are beginning to take on the importance for consumers, such as the Nordic Ecolabel, which is recognized by $95 \%$ of consumers in the Nordic countries (Martínez Rodrígez, Mayorga-Pérez, Vera-Martínez, \& García Morales, 2018).

\section{Ecolabels in Mexico}

Mexico has its certifications and eco-labels that are relevant to the environment such as the Organic SAGARPA Mexico label, certified by the Organic Products Law, and the Monarch Butterfly eco-label, based on the Mexican Standard NMX-N-107-SCFI-2010 that establishes the minimum content of recycled fiber for the manufacture of paper that varies between 50\% and 80\% (Alianza del Pacífico \& Chile-Mexico Cooperation Fund, 2017).

These eco-labels are a precedent of certifications based on Official Mexican Standards and Laws that regulate products marketed within Mexican territory, which could be used in disposable products. Mexico has ecolabels for sustainable consumption in six consumer segments:

- $\quad$ Food and drinks.

Cosmetics and personal care.

Cleaning.
- $\quad$ Paper, furniture, and construction.

- $\quad$ Energy and electronics.

- $\quad$ Labels for companies.

However, disposable products such as diapers are not considered in any of these classifications, when this type of product generates a significant percentage of solid waste as previously discussed. The extraction of raw materials from non-renewable sources, their transport, their useful life, and their way of disposal have a great environmental burden.

\section{Prospective of ecolabels on disposable diapers}

The sustainable development objectives of the 2030 agenda indicate that scientific and technological capacity must be strengthened to reduce the generation of waste, therefore, the life cycle analysis and regulations should be a strategy to defend the resources of future generations that are currently being consumed in disposable products. Promoting the knowledge of this type of indicator to consumers would result in responsible consumption (Government of Mexico, 2020).

The design of the disposable diaper, the way it is produced, transported, and disposed of is not sustainable. Obtaining raw material from non-renewable sources to use in products whose useful life is six hours, has resulted in the environmental crisis that afflicts humanity.

The layers of disposable diapers are manufactured from polyethylene and polypropylene (polymers), which should be degradable to recover organic matter, as indicated in NMX-E-273-NYCE-2019, which establishes the minimum specifications of plastics that are suitable for organic recovery through aerobic composting.

There are four characteristics that the Mexican Standard evaluates so that plastics can be classified as compostable:

1) Biodegradation.

2) Disintegration during composting.

3) Negative effects on the composting process. 
4) Negative effects on the quality of the compost, including the presence of high levels of regulated metals and other harmful components (Normalization and Certification NYCE, S.C., 2020).

The standard applies to all compostable plastic products and materials that are manufactured, marketed, and distributed in the Mexican national territory, this could be the basis for designing a label for disposable products such as diapers, due to the volume that is produced and disposed of. This would force companies to design products with a short useful life with highly biodegradable materials, which would generate a valued waste such as compost.

The objective of labels for sustainable consumption is to use marketing as a tool to highlight products whose production process is friendly to the environment and that represent a lower burden on the environment.

The use of eco-labels as an educational strategy would work to inform the consumer of the products that have a lower load, reducing the use of products with a greater environmental load, as mentioned in the "Educate $\mathrm{Me}$ Program." If the consumer is instucted in the management and treatment of waste, urban waste could decrease significantly (Alvarado Pereda, 2021)

\section{Discussion of Results}

The objective of this review is to make visible the existing regulations to market disposable diapers in the Mexican territory and prospect a regulation that regulates and establishes the guidelines and requirements for disposable diapers to achieve the sustainable development objectives of the 2030 agenda.

It was found in this study that the Official Mexican Standards do not regulate:

Materials for the design of disposable products.

The life cycle analysis (LCA) of the products.

- $\quad$ Management of this waste.

Indicators apply to products of this type that reflect the environmental damage caused by production processes.
The Mexican Standard NMX-E-273NYCE-2019 indicates the characteristics that the materials must have so that they can be classified as suitable for organic recovery through aerobic composting, generating a valued waste, which could help another sector to reduce its environmental impact and closing the product life cycle from cradle to cradle, being an ecoefficiency indicator that functions as a strategy to regulate the impact of Mexican companies, obtaining benefits by making their processes and resources more efficient (Martínez Rodrígez, Mayorga- Pérez, Vera-Martínez, \& García Morales, 2018).

\section{Conclusions}

The disposable diaper is a product that has helped improve the quality of life of modern families, however, the consumption of this product is causing air and soil pollution because:

- Extract the materials for the manufacture of this product is from non-renewable sources.

- The materials used for manufacturing are virgin, none is recycled or reused.

- The short shelf life of the product (six hours).

\section{- $\quad$ Materials are resistant to degradation.}

Mexico is a country that is interested in safeguarding natural resources and for this reason it has implemented norms and laws that support eco-labels, which indicates that it is possible to design a government agent based on environmentally friendly norms and processes that certify and regulate the disposal of disposable products that are generated from commercial activity.

On the other hand, Mexico is one of the countries that committed to achieving the objectives of the 2030 agenda, a great advance in the development of sustainable cities and communities would be achieved if this type of disposable products were regularized and scientific and technology of companies to develop materials suitable for the useful life of the product. 
If eco-labels are promoted based on the Official Mexican Standards, the companies that manufacture disposable products would advance towards the development of clean processes, achieving products whose life cycle would have less impact than the current ones that are marketed, and could significantly reduce the quantity of solid waste generated.

\section{Acknowledgments}

To the National Council of Science and Technology (CONACYT) for the scholarship granted to carry out this study.

The Universidad Autónoma de Querétaro for the institutional scholarship for postgraduate study.

\section{References}

Alavarado Pereda, F. N. (2021). Programa Edúcame en gestión de residuos sólidos domésticos en familias del comedor popular Santísimo Salvador, Las Palmas del Distrito Pachacamac. In Tesis doctoral (pp. 90-98). Lima.

Alianza del Pacífico. Fondo de Cooperación Chile México. (2017). Guía de Etiquetas para un Consumo Sustentable.

Blume-Peytavi, U., \& Kanti, V. (2018). Prevention and treatment of diaper dermatitis. Wiley Pediatric Dermatology, 19-23. doi:https://doi.org/10.1111/pde.13495

Conaco y Servytur México. (2018). Indicadores Querétaro. 0-9.

Cordella, M., Bauer, I., Lehmann, A., Schulz, M., \& Wolf, O. (2015). Evolution of disposable baby diapers in Europe: life cycle assessment of environmental impacts and identification of key areas of improvement. Journal of Cleaner Production, 95, 322-331. Retrieved from (http://creativecommons.org/licenses/by/4.0/).

EDANA. (2019). Retrieved marzo 3, 2020, from Baby diapers. The benefit of baby diapers: https://www.edana.org/nw-relatedindustry/nonwovens-in-daily-life/absorbenthygiene-products/baby-diapers

Gobierno de México. (2020). México agenda 2030. Retrieved $11 \quad 19$, 2020, from https://www.gob.mx/agenda2030
Hauschild, M. Z., Rosenbaum, R. K., \& Olsen, S. I. (2018). Life Cycle Assessment. Switzerland: Springer. doi:10.1007/978-3-319-56475-3

Instituto Nacional de Normalización Textil, A.C. (2020). INNTEX. Retrieved from http://inntex.infored.mx/1925639_INNTEX.ht $\mathrm{ml}$

Mahecha Bustos, G., \& Romero Venegas, A. P. (2021). Establecimiento de un plan de manejo para la gestión integral de los residuos gnerados en cuatro fincas aguacateras en la vereda $\mathrm{La}$ Montaña, ubicada en el minucipio de Caparrapí. In Tesis Profesional (pp. 80-83). Bogotá.

Martínez Rodrígez, M. C., Mayorga-Pérez, O., Vera-Martínez, M. C., \& García Morales, M. I. (2018). Eco.etiquetado y productos verdes: Desarrollo y competitividad. Tecnología en marcha, $31(2)$. doi:http://dx.doi.org/10.18845/tm.v31i2.3626

Mendoza, J. M., D’Aponte, F., Gualtieri, D., \& Azapagic, A. (2018). Disposable baby diapers: Life cycle costs, eco.efficiency and circular economy. Journal of Cleaner Production, 1-23. doi:https://doi.org/10.1016/j.jclepro.2018.11.14 6

Mendoza, J., D’Aponte, F., Gualtieri, D., \& Azapagic, A. (2018). Disposable baby diapers: Life cycle costs, eco-efficiency and circular economy. Journal of Cleaner Production. doi:https://doi.org/10.1016/j.jclepro.2018.11.14 6.

Mirabella, N., Castellani, V., \& Sala, S. (2013, febrero). Life cycle assessment of bio.based products: a disposable diaper case study. Int $J$ Life Cycle Assess(18), 1036-1047. doi:https://doi.org/10.1007/s11367-013-0556-6

Muñoz, M. J. (2003). Higiene y cuidados de la piel del bebé. Elsevier, 22(3), 6. Retrieved marzo 24, 2020, from https://www.elsevier.es/esrevista-offarm-4-articulo-higiene-cuidados-pieldel-bebe-13044453

Normalización y Certificación NYCE, S.C. (2020, mayo 6). Publican NMX de plásticos compostables. Retrieved octubre 12, 2020, from https://www.nyce.org.mx/publican-nmx-deplasticoscompostables/\#iLightbox[gallery32851]/null 
OVAM. (2020). Define the environmental impact of your product and make a difference! Retrieved 11 21, 2020, from ecolizer tool: http://www.ecolizer.be/

Pozos Vázquez, C., Blanco Padilla, P., Mercado González, M., \& Vélez Martínez, G. A. (2018). Almohadilla desechable biodegradable a ser usada en un pañal ecológico. European Scientific Journal, $14, \quad 37-47$. doi:10.19044/esj.2018.v14n12p37

Procuraduría Federal del Consumidor. (2019). Pañales desechables para bebé. Con lo mejor de la revista del Consumidor, 9.

Secretaria de Economía. (2016). Gobierno de México. Retrieved 3 21, 2020, from https://www.gob.mx/se/acciones-y-

programas/competitividad-y-normatividadnormalizacion

Secretaría de Economía. (2019). Diario Oficial de La Federación. Retrieved from https://www.dof.gob.mx/nota_detalle.php?codi go $=5263188 \&$ fecha $=10 / 08 / 2012$

Secretaría de medio ambiente y recursos naturales. (2004). Norma Oficial Mexicana NOM-098-SEMARNAT-2002, Protección ambiental - incineración de residuos, especificaciones de operación y límites de emisión de contaminantes. Distrito Federal: Diario Oficial.

Sotelo Navarro, P. X. (2017). Producción de bioH2 por fermentación oscura a partir de pañales desechables usados. Ciudad de México: Universidad Autónoma Metropolitana, Azcapotzalco 